\title{
Maioridade aos 18 anos
}

\section{Cesarino Junior}

Estamos procedendo à revisão do Código Civil. E, portanto, oportuno cogitar de certas reformas que a época impõe. Uma delas é, exatamente, a questão da idade em que se deve fixar a maioridade civil.

Não é de estranhar-se cogite do assunto um professor de Direito Social. Já foi ele criticado, mais de uma vez, por atribuir ùma função absorvente à sua disciplina... Mas, a realidade é que o sentido social é hoje comum a todos os ramos do Direito, embora se haja concentrado no que se chama o Direito Social Restrito ou Direito Social tout court. Daí que caiba a ele tambem preocupar-se com o problema da modificação da idade em que o indivíduo deve ser declarado maior, mesmo porque é ele um precursor nestes assuntos.

Com efeito, na Italia, a capacidade para a celebração do contrato individual de trabalho tende a fixar-se nos 18 anos. $O$ mesmo acontece, entre nós, quanto à capacidade para estar em juizo (na Justiça do Trabalho), não se exigindo dos menores (púberes) a assistência dos pais ou tutores, para poderem litigar em questões' oriun'das de contrato de trabalho.

Aliás em nossa legislação, mesmo constitucional, já se verifica uma tendência neste sentido, pois os maiores de 18 anos, embora civilmente incapazes, têm sido considerados politicamente capazes, visto como se lhes concedeu o direito de alistar-se como eleitores e, consequentemente, de votar. Chegou-se assim ao absurdo de se permitir a uma pessoa a intervenção nos próprios destinos da nacionalidade, embora se continue a considerá-la incompetente para di-, rigir os próprios destinos individuais.

A realidade está a exigir uma solução mais exata. Não estamos mais na época em que um homem de 25 anos era ainda um donzelão.. Os imperatívos do dinamismo da vida moderna, complicando e dificultando a existência, aproveitando o trabalho de quasi crianças, e, assim, pondo-as mais cedo em íntimo contacto com os problemas do struggle for life, indicam a necessidade dessa revisão. 
Os vendedores de jornais, os empregados, os office boys, são todos ou quasi todos, sinão meninos, porque é proibido o trabalho antes dos 14 anos, pelo menos profundamente jovens. Não temos em mãos, no momento, dados estatísticos, mas as observações mais ou menos empíricas que temos feito, nos hão convencido de ser muito grande o número de jovens que não somente trabalham, mas trabalham em cargos de responsabilidade, constituem família e apresentam já apreciavel contribuição ao progresso da civilização, em todos os seus setores.

o dinamismo, a rapidez é - já o dissemos - um imperativo do século. Com razão dizia Kilpatrik que, o que é da véspera, hoje em dia, já é caduco. Logo, porque manter a ficção de que os indivíduos de menos de 21 anos são juridicamente incapazes, quando, de fato, realisticamente, eles, entre os 18 e 21 anos, são muitas vezes mais capazes que seus próprios pais? Não é certo que os jovens de hoje, sejam quais forem as suas condições econômicas, têm, quasi sempre, mercê da contribuição do rádio, do cinema, da imprensa, muito mais cultura que seus próprios pais?

Aliás, o próprio Código Civil permite já a emancipação aos 18 anos, por outorga dos pais ou tutores.

Porque não generalizar a medida, estabelecendo o novo Código, Civil que a maioridade civil começa aos 18 anos completos? 